\title{
IMPLEMENTASI BAHASA ADAT MOMBESARA PADA PROSES UPACARA ADAT PERKAWINAN MASYARAKAT SUKU TOLAKI DI KOTA KENDARI
}

\author{
ALAN \\ Universitas Lakidende Unaaha \\ e-mail: alanlibra1986@gmail.com
}

\begin{abstract}
ABSTRAK
Bahasa sebagai sarana komunikasi antar penuturnya mempunyai peranan penting dalam kehidupan sehari-hari, karena manusia dalam beraktivitas tidak terlepas dari manusia lain, bahkan dengan lingkungan sekalipun. Dalam upaya memenuhi kebutuhan kita sehari-hari bahasa sangatlah perlu di gunakan baik lisan maupun tulisan. Bahasa adalah alat komunikasi antar sesama, dalam hubungan antar sesama penutur bahasa yang sama antar penutur bahasa yang lainnya. Dalam mempergunakan bahasa baik sebagai alat komunikasi sesama penutur membutuhkan pengetahuan untuk menginplementasikan bahasa itu sendiri. Telah kita ketahui bersama bahwa bahasa adat masing-masing suku mempunyai ciri khas masing-masing. Kemudian pada upacara adat perkawinan suku tolaki terdapat suatu adat yang di pertahankan keberadaannya, dan menjadi warisan budaya leluhur nenek moyang suku tolaki, dan bukan itu saja, adat mombesara ini sebagian besar warga masyarakat kendari sudah menjadikan ikon dalam melaksanakan upacara adat perkawinan mereka yang bersuku tolaki. Tentunya dalam upacara tersebut terdapat kata-kata yang sering digunakan oleh pembicara-pembicara yang terlibat dalam acara tersebut yaitu yaitu bahasa mombesara. Dari permasalahan tersebut diatas, peneliti berusaha mencari tahu implementasi bahasa adat mombesara pada upacara adat perkawinan suku tolaki di kota Kendari dengan metode kualitatif. Dalam metode kualitatif ini, peneliti menentukan dan memilih informan sesuai dengan tujuan penelitian (purposive) yakni informan dari tolea yaitu penutur adat Mombesara dari pihak laki-laki, Pabitara merupakan penutur adat Mombesara dari pihak perempuan dan tokoh Adat, tokoh Agama dan Pemerintah setempat yang sering dihadirkan dalam upacara tersebut, dan yang mengetahui dan memahami hal-hal yang berkaitan dengan masalah penelitian. Teknik pengumpulan data penelitian ini terdiri dari (1) observasi (2) wawancara mendalam (deep interview), dan (3) penelusuran kepustakaan. Hasil penelitian ini akan disajikan dengan menggunakan teknik informal dan formal. Secara informal, hasil penelitian ini disajikan dalam bentuk narasi karena makna teks bersifat verbal dan memiliki struktur naratif dengan mengikuti kaidah penulisan ilmiah. Secara formal, hasil penelitian ini disajikan melalui gambar, foto, peta dan lain sebagainya.
\end{abstract}

Kata Kunci: Implementasi; Bahasa; Adat Mombesara. 


\section{LATAR BELAKANG}

Bahasa sebagai sarana komunikasi antar penuturnya mempunyai peranan penting dalam kehidupan sehari-hari, karena manusia dalam beraktivitas tidak terlepas dari manusia lain, bahkan dengan lingkungan sekalipun. Dalam mempergunakan bahasa baik sebagai alat komunikasi sesama penutur membutuhkan pengetahuan untuk menginplementasikan bahasa itu sendiri.

Di Sulawesi tenggara tradisi adat istiadat dan budaya ini selalu dikaitkan dengan kebiasaan penting dalam kehidupan, Berbagai jenis kegiatan tradisi adat istiadat mengambil kegiatan yang berkaitan dengan kebiasaan para leluhurnya seperti upacara perkawinan dan upacara-upacara ritual lainnya. Pada upacara adat perkawinan suku tolaki terdapat suatu adat yang di pertahankan keberadaannya, dan menjadi warisan budaya leluhur nenek moyang suku tolaki, dan bukan itu saja, adat mombesara ini sebagian besar warga masyarakat Kendari sudah menjadikan ikon dalam melaksanakan upacara adat perkawinan mereka yang bersuku tolaki. Tentunya dalam upacara tersebut terdapat kata-kata yang sering digunakan oleh pembicara- pembicara yang terlibat dalam acara tersebut yaitu bahasa mombesara.

Salah satu Tradisi dan budaya yang ada di Sulawesi Tenggara adalah upacara perkawinan suku Tolaki dengan menggunakan bahasa mombesara yang mempunyai empat tahapan yaitu tahap morake-rakepi, monduutudu, mowawo niwule dan mowindahako pada tahap ini mengunakan bahasa daerah Tolaki yang di perankan oleh Pabitara dan Tolea. Tradisi ini salah satunya berada di salah satu kawasan Sulawesi Tenggara khususnya di kota Kendari dan sampai saat ini masih tetap dipertahankan keberadaannya secara turun temurun.

Bahasa yang digunakan dalam implementasi bahasa mombesara yakni: a) harus memakai bahasa daerah tolaki yang asli. b) bentuk tuturan adatnya harus disesuaikan dengan konteks pelaksanaan adat tersebut. Terjadinya proses Mombesara adanya dialog antara Tolea dari pihak laki-laki dan Pabitara dari pihak perempuan yang membicarakan masalah yang ada dalam adat suku tolaki.

Beberapa penelitian terdahulu memperlihatkan bahwa bahasa adat mombesara pada upacara adat perkawinan masyarakat suku Tolaki belumlah sepenuhnya diimplementasikan. Kusnan (2010) menemukan bahwa makan ungkapan yang ada dalam upacara adat perkawinan dibutuhkan pengetahuan bahasa dan pengalaman yang luas bagi para pelakon dan pendengar. Lucken (2013) menemukan bahwa penggunaan dari Kalosara adalah lambang pemersatu dan perdamaian yang sangat sakral dalam kehidupan Suku Tolaki tetapi kenyataannya masih banyak yang belum mengetahui makna dari kalosara tersebut. Berdasarkan hal tersebut, peneliti tertarik untuk meneliti bagaimana implementasi bahasa adat mombesara pada upacara adat perkawinan suku tolaki di kota kendari.

\section{METODE PENELITIAN}

Metode penelitian ini adalah cara-cara ilmiah yang dilakukan dalam kegiatan riset, termasuk perencanaan sampai dengan hasil penelitian berupa laporan penelitian ilmiah. Keseluruhan kegiatan penelitian ini meliputi tahap pengumpulan data, tahap analisis data serta tahap penyajian analisis.

Penelitian ini adalah penelitian deskriptif kualitatif yaitu mengarahkan upaya pada pemahaman yang baik dibalik ide, gagasan, perasaan motif atau keyakinan. Secara khusus penelitian berfokus pada implementasi bahasa mombesara pada upacara adat perkawinan suku tolaki di kota Kendari. Penelitian ini berusaha menganalisis 
suatu fakta atau kejadian dari objek itu sendiri penelitian memasuki lapangan dan menemukan data dari informan yang diperoleh secara alamiah. Dalam metode kualitatif ini, peneliti menentukan dan memilih informan sesuai dengan tujuan penelitian (purposive) yakni informan dari tolea yaitu penutur adat Mombesara dari pihak laki-laki, Pabitara merupakan penutur adat Mombesara dari pihak perempuan dan tokoh Adat, tokoh Agama dan Pemerintah setempat yang sering dihadirkan dalam upacara tersebut, dan yang mengetahui dan memahami hal-hal yang berkaitan dengan masalah penelitian.

\section{HASIL PENELITIAN}

\section{Proses Upacara Adat Mombesara}

Upacara adat mombesara adalah suatu proses penyampaian perangkat adat dalam upacara adat perkawinan suku tolaki dengan menggunakan bahasa klasik suku tolaki, Mombesara adalah sebagai salah satu Budaya Tolaki dalam melaksanakan proses upacara perkawinan suku tolaki. Dalam hal ini mombesara dilibatkan dua pembicara yaitu tolea dan pabitara. Mombesara mempunyai banyak tuturan yang berbeda, karena dalam pelaksanaan perkawinan suku tolaki terdapat empat tingkatan yaitu tahap morake-rakepi, monduutudu, mowawo niwule dan mowindahako. Bila memandang tuturan mombesara sebagai sesuatu yang bermakna, maka seseorang tersebut akan mampu menghayati kehidupan budaya.

Tuturan mombesara merupakan suatu aturan yang mengatur budaya antara pihak perempuan dan pihak laki-laki dan mengatur budaya manusia dan sesamanya yang bersifat gagasan dan kebenaran.Upacara pernikahan suku tolaki merupakan salah satu upacara tradisional yang dilakukan secara turun - temurun dan berlaku secara umum pada suku tolaki. Artinya upacara tradisional ini dilaksanakan tanpa mengenal adanya strata sosial atau tidak adanya perbedaan miskin dan kaya. Dapat diketahui bahwa yang terkandung dalam tuturan mombesara bersifat kultural, artinya pendukung kegiatan ini cenderung beranggapan bahwa makna-makna bahasa itu akan berlaku disetiap lini kehidupan suku tolaki, jadi anggapan sikap kolektif yang menjadi ciri khas setiap kelompok budaya masyarakat penganutnya. Proses mombesara yang dilaksanakan oleh pembicara dari pihak laki-laki yang disebut tolea dan pembicara dari pihak perempuan disebut pabitara. Dalam tahap Mombesara ini terdapat empat tingkatan yaitu tahap morake-rakepi, monduutudu, mowawo niwule dan mowindahako yang dilibatkan pembicara dari pihak laki-laki (tolea) dan pembicara dari pihak perempuan (pabitara). Penutur Tolea merupakan penutur kunci atau inti dalam setiap pelaksanaan upacara adat Mombesara yang merupakan juru bicara dari pihak laki-laki, sedangkan penutur pabitara merupakan penutur pelengkap yang merupakan pemberi jawaban atas pertanyaan adat berupa tuturan Mombesara dari piahak perempuan dalam setiap pelaksanaan upacara adat perkawinan etnis tolaki.

Tuturan Mombesara pada setiap pelaksanaan adat perkawinan etnis Tolaki, bentuk tuturannya beragam, unik dan berbeda bentuk tuturannya, yang dituturkan oleh tolea dan pabitara. Bahasa adat yang dipergunakan dalam tuturan adat mombesara yakni:

1. Ragam bahasa tolaki standar (kuno)

2. Menggunakan Bahasa Daerah Tolaki yang asli dan benar

3. Tuturannya harus sesuai dengan konteks tahap perkawinan 
Pelaksanaan upacara adat perkawinan (mowindahako) pada etnis tolaki dimulai dari beberapa tahap, tahapan yang dimaksud adalah:

1. Tahap Morake-rakepi (mengikuti dan meninjau calon istri)

2. Tahap Monduutudu (tahap pelamaran jejaka)

3. Tahap Mowawo niwule (tahap pelamaran sesungguhnya)

4. Tahap Mowindahako (tahap upacara perkawinan/pernikahan)

Dalam prosesi adat mombesara ini terdapat aturan lain didalamnya, yaitu syarat isi adat yang harus dipenuhi oleh pihak laki-laki, diantaranya adalah Puu'uno Osara (pohonnya Adat) meliputi :

1. Tawa-tawa sara (gong adat)

2. Kiniku sara (kerbau adat) dan eno sara (kalung adat)

3. Tawano osara (daun-daunnya) meliputi: kaci, sarung, periuk, kain penggendong bayi dan kelengkapan adat lainnya.

Adapun tata cara atau tahapan pelaksanaan upacara adat perkawinan masyarakat suku tolaki yakni:

\section{Tahap Pertama Morake-rakepi}

Tahap ini di awali dengan adanya penyampaian dari seseorang anak muda lakilaki kepada orang tua bahwasannya dia telah mempunyai pilihan hati seseorang gadis yang akan dijadikan sebagai pendamping hidupnya. Jika orang tua menyetujui maksud hati tersebut, maka mereka akan mengadakan musyawarah. Dalam musyawarah ini biasanya melibatkan saudara-saudara sekandung dari pihak ayah dan saudara-saudara sekandung dari pihak ibu. Kemudian disepakati hari yang tepat untuk kerumah orang tua si gadis tersebut. Yang berangkat biasanya adalah 3 atau 4 orang atau bisa saja satu orang saja yang mewakili dari pihak keluarga laki-laki. Dalam rombongan kecil ini dipilihlah satu orang sebagai kepala rombongan. Kepala rombongan yang ditunjuk ini haruslah seorang yang memiliki kemampuan yang berkomunikasi yang baik dalam artian dapat menyampaikan sesuatu maksud dengan jelas dan tepat serta mampu untuk berbasa-basi.

Jika rombongan dari pihak keluarga laki-laki telah sampai dirumah orang tua perempuan maka setelah mengucapkan salam dalam dan berbasa-basi, kepada rombongan kemudian Mombowuleako (menyuguhkan daun sirih dan pinang, kadangsadang daun sirih dan pinang ini sudah diganti dengan sebungkus rokok) kepada tuan rumah. Dalam keadaan normal seharusnya tuan rumahlah yang menyuguhkan sirih pinang atau rokok kepada tamunya. Jika sudah demikian, maka tuan rumah (orang tua perempuan) telah mengerti bahwa kedatangan baik rombongan maupun perorangan ini datang bertamu dengan tujuan untuk membicarakan masalah perjodohan.

Dalam komunikasi antara rombongan keluarga laki-laki dengan orang tua perempuan, tidak secara lugas/tegas atau langsung ditanyakan bahwa maksud dan tujuan kedatangan tamu ini adalah untuk membicarakan masalah perjodohan tetapi ditanyakan dengan memakai bahasa kiasan seperti bahwa rombongan ini sedang berjalan-jalan untuk mencari tempat membuka lahan perkebunan. Orang tua perempuan juga tidak secara langsung menjawab bahwa benar dia memiliki anak gadis tetapi dia akan menjawab pulanglah dahulu dan nanti kita akan mencoba mencarikan tempat untuk berkebun. Jika sudah demikian adanya, maka rombongan ini sudah dapat meninggalkan rumah perempuan dengan satu pengharapan bahwa segera mungkin mereka akan mendapatkan jawaban agar dapat dilanjutkan ketahap selanjutnya. 
Pada saat rombongan ini meninggalkan rumah orang tua perempuan, niwule (daun sirih dan pinang) atau rokok wajib / harus ditinggalkan dirumah orang tua perempuan. Masa penantian jawaban dari orang tua perempuan adalah 4 hari sampai dengan maksimal 2 jumat (ruo dumaa) atau 2 minggu. Dalam masa penetian ini, orang tua perempuan dapat menggutus seseorang kepada orang tua laki-laki bahwa urusan selajutnya sudah dapat di laksanakan atau urusan perjodohan itu tidak perlu di lanjutkan dengan berbagai alasan dan pertimbanggan. Jika orang tua perempuan tidak mengirim utusan untuk memberikan kepastian kepada orang tua laki-laki, maka hal itu di anggap bahwa orang tua perempuan telah setuju agar urusan perjodohan ini di lanjutkan ketahap berikutnya.

\section{Tahap Kedua Monduutudu (Pelamaran Penjajakan)}

Pelamaran penjajakan diawali dengan pihak keluarga laki-laki mengirim utusan kepada keluarga pihak perempuan untuk menyampaikan bahwa keluarga pihak lakilaki akan berkunjung dan meminta kesiapan waktu dari pihak keluarga perempuan. Jika pihak keluarga perempuan telah memberikan waktu untuk kedatangan pihak keluarga laki-laki, maka keluarga laki-laki sesuai dengan waktu yang telah disepakati bersama kedua belah pihak akan kembali mengirim utusan yang terdiri atas : Tolea yang berperan sebagai duta perwakilan atau juru bicara yang disertai dengan keluarga dekat, baik dari pihak bapak maupun dari pihak ibu laki-laki yang akan dikawinkan atau dinikahkan. Untuk menerima kedatangan rombongan pihak laki-laki, maka dari pihak perempuan akan diwakili oleh Pabitara yang juga berperan sebagai duta atau juru bicara yang didampingi oleh keluarga dekat pihak keluarga perempuan yang sebelumnya telah ditunjuk.

Setelah semuanya hadir dirumah keluarga pihak perempuan, kemudian duduk di atas lantai yang telah diberi alas di suatu ruangan. Kedua pihak keluarga duduk berhadapan dan masing-masing duduk paling muka adalah Tolea dari keluarga pihak laki-laki dan Pabitara dari keluarga perempuan.

Acara yang dimulai oleh Tolea dengan meletakan Kalosara, (kalosara ini diletakan dalam sebuah wadah persegi yang disebut dengan Siwole yang dilapisi dengan kain putih dihadapannya) dan di hadapan Pabitara. Ditengah lingkaran Kalosara diletakan selembaran daun sirih dan di atas daun sirih diletakan pula sebiji buah pinang muda. Sebelum memulai, Tolea meletakkan selembar uang 10.000 di dekat daun sirih dan pinang muda. Pabitara kemudian memegang wadah kalosara/siwole.

Setelah pabitara memegang wadah tempat diletakkan kalosara maka tolea kemudian memulai pembicaraan. Pembicaraan ini disampaikan dengan bahasa yang halus yang tujuannya memohon ijin untuk memulai acara. Kata-kata tolea seperti berikut (Wawancara Alan Minggu 20 September 2020 di kecamatan Wua wua kelurahan Anawai).

Kata - kata Tolea dari pihak laki - laki

Inggomiu mbulipu-mbuwonua

Inggomiu mburaha-mbulaika

Inggomiu anamotuo-toono meohai

Inggomiu pabitara 


\section{Tuduito resaito}

Mepoluhu-mepokudepe

Mepotira-mepokulelo

Osara peowai

Iraimiu ipembolawamiu

Pombudinggu mbulipu - pombeowosenggu mbuwonua

Pombudinggu mburaha - pombeowosenggu mbulaika

Pombudinggu anamotuo - pombeowosenggu toono meohai

Pombudinggu tolea - pombeowose ine pabitara

Pondibanggu osara - pobosinggu peowai

Baara laipo nio nggotine oluolunggako

Maa nggoariikaahae keinggomiu

Moweekomami potiso

\section{Artinya:}

Yang kami hormati penghuni kampung

Yang kami hormati pihak tuan rumah

Yang kami hormati pihak yang dituakan, keluarga dan kerabat

Yang kami hormati pihak juru bicara (tolea)

Sudah turun - sudah teletak

Sudah nampak - sudah terlentang

Sudah dipersembahkan - sudah diperhadapkan

Adat negeri-warisan leluhur

Dihadapan juru bicara - ditengah hadirin

Penghargaan kami kepada penghuni kampung

Penghargaan kami kepada tuan rumah

Penghargaan kami kepada pihak yang dituakan, keluarga dan kerabat

Penghargaan kami kepada pihak juru bicara

Sebagai alas kata-pembuka kalimat

Untuk memohon penjelasan

Apakah acara adat sudah dapat dilaksanakan

Ataukah masih ada pihak yang perlu dinanti

Mohan kiranya dari pihak juru bicara

Dapat memberi petunjuk pada kami

Pada penuturan awal pembuka kata, seperti biasanya yaitu pemberian bentuk penghormatan kepada tuan rumah, pihak yang dituakan serta pemberian penghormatan kepada keluarga dan kerabat. Adapun tuturan mombesara menurut Tolea bahwa sudah lama mereka ingin memendam rasa kepada keluarga anak gadis tersebut. Serta adanya suatu keinginan pihak laki - laki untuk menyambung tali silahturahmi kepada keluarga perempuan apabila ada anak gadis yang belum dilamar kami punya niat untuk melamarnya dalam bahasa puitisnya (Andai ada semak belukar yang sudah pantas untuk dirambah, kami memiliki hati yang sungguh - sungguh untuk menjadikan kebun peliharaan). 
Gambar Tolea dan Pabitara

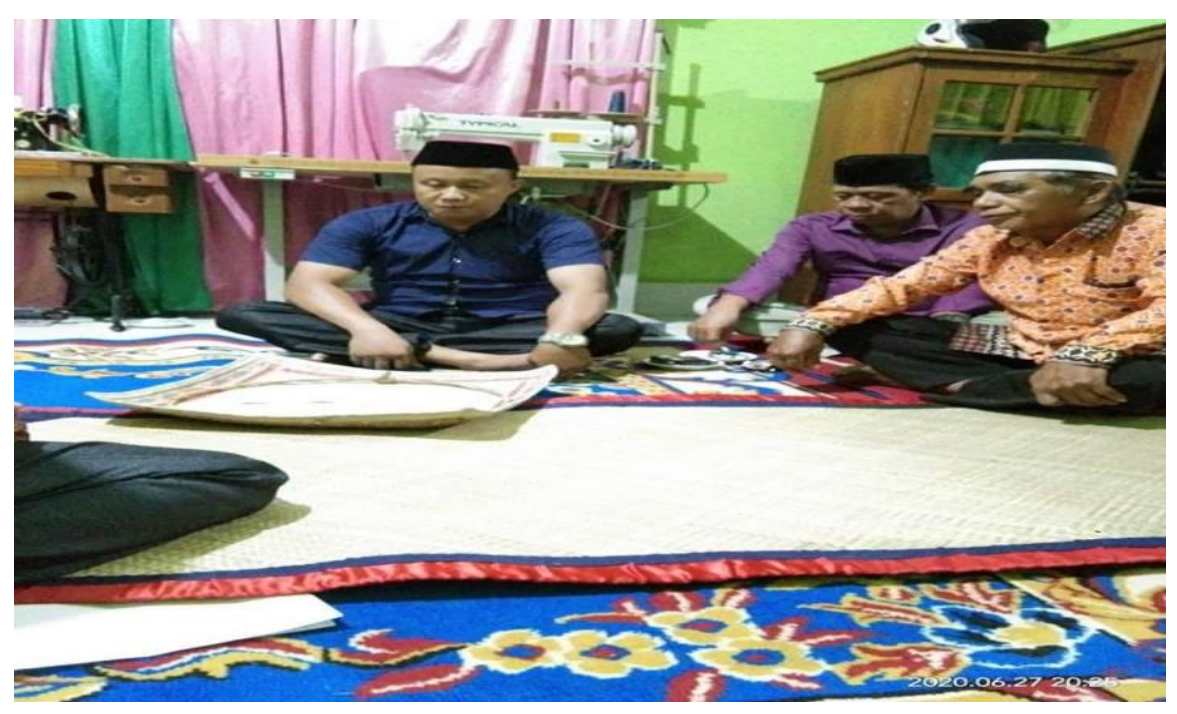

\section{Tahap Ketiga Mowawo Niwule (Peminangan Resmi)}

Jika pihak keluarga perempuan telah memberikan ketetapan waktu untuk peminangan kepada pihak keluarga laki-laki, maka tahap selanjutnya adalah tahap mowawo niwule. Tahap ini merupakan tahap pelamaran/peminangan secara resmi dan biasa juga disebut acara mesarapu (tunangan). Pada tahap ini baik pihak keluarga lakilaki maupun keluarga pihak perempuan sudah dapat mengikutsertakan banyak orang untuk menghadirinya. Pihak keluarga laki-laki tetap dipimpin oleh tolea dan pihak keluarga perempuan oleh pabitara, selain itu yang juga wajib hadir dalam acara ini adalah unsur pemerintah yakni kepala desa atau lurah, puutobu (Ketua Adat), dan para petua adat setempat. Acara ini dapat dimulai jika kepala desa atau lurah serta puutobu dimana acara ini diadakan telah hadir.

Adapun acara ini berlangsung dimulai dengan sara papalalo ine ulu sara / sara mbeparamesi (Adat memohon izin untuk dimulainya acara kepada pemerintah). Pada sara mbeparamesi ini diserahkan amplop berisi uang dari tolea kepada pemerintah setempat sebesar antara Rp. 25.000 - Rp. 50.000, dan amplop untuk kas desa /kelurahan sebesar Rp. 25.000 atau sesuai keputusan desa. Kata-kata tolea dalam sara papalalo ine ulu sala/sara mbeparamesi sebagai berikut, (Wawancara Alan Sabtu 12 September 2020, Kecamatan Wua wua Kelurahan Mataiwoi)

Inggomiu ulusala - puи bawaa

Pineowosenggu - pinokulaloinggu

Laala kumunggu ananiwawao - melolumii toononggapa

Nde pesukoaa-pombependee.

Tuduito - resaito

Mepotira-mepokulelo

Saranano wonua

Iwoimiu - iraimiu.

Laa dunggu mesuko - limba mombeendee

Keno onggoto tewali - la tehodoano

Noonggo pinokolako o sara-niduako peowai

Hende-hende la pinembereu - rehuakondo - pinendeporombuakondo

Nggo inggomiukaahae moweekomami pondototoki. 


\section{Artinya:}

Yang kami hormati

Pihak pemerintah setempat sebagai pimpinan tertinggi

Yang memimpin aparat dan yang mengayomi seluruh warga

Tempatnya segala pertimbangan dan putusan.

Sudah turun - sudah terletak

Sudah dipersembahkan - sudah diperhadapkan

Adat negeri-warisan leluhur

Dihadapan yang terhormat

Kami datang memohon petunjuk

Kiranya mungkin sudah dapat diizinkan

Acara adat untuk dilaksanakan

Seperti maksud utama pertemuan ini

Segala keputusan ada pada yang terhormat.

Sebagai tanda penerimaan, pihak pemerintah dalam hal ini adalah kepala desa/Lurah, membalas tuturan adat yang di ucapkan oleh Tolea. Sedangkan bentuk atau isi tuturan yang dituturkan oleh pemerintah menyangkut pemberian izin kepada Tolea untuk melaksanakan adatnya atau melanjutkan adatnya sesuai dengan ketentuan atau maksud dan tujuan kedatangan mereka kepada pihak keluarga perempuan. Pihak pemerintah setempat memegang perangkat adat kalosara pada bagian simpulnya dengan tangan kanan sambil memberikan jawaban antara lain sebagai berikut.

Tumotahaikomiu tuluramiu tolea

Hende la pesukomiu - pombependeemiu

Keno onggoto tewali - laa tehodoano

Nopinokolako osara - nidiuu ako peowai

Hende-hende laa pinembererehuakondo pinendeporombuakondo.

Ari ine pamarenda

Mbuoto pomboletino

Keno kuuto - keno koato

Tepumbu-teporombu

Nggoongo mererehu sara - laa ninaa motuo

Inggoto mokolakokeito

Ano petenggano - ano pedederano.

Hongario kenolaambo

Nggo tinebaraako - tineoluolungako

Maa ionggoki mesuko mombependee keihiro toono motuo.

\section{Artinya:}

Menjawab pembicaraan tolea

Seperti apa yang dipertanyakan

Kiranya mungkin sudah dapat dizinkan

Acara adat untuk dilaksanakan

Seperti maksud utama pertemuan ini.

Dari pihak pemerintah setempat

Sudah tidak ada hambatan.

Bila sudah lengkap

Duduk menghadap di forum ini 
Kalangan tertua adat yang dibutuhkan

Kiranya acara adat sudah dapat dilaksanakan

Menurut tingkat-tingkat pembicaraannya.

Akan tetapi bila masih ada

Pihak yang masih perlu dinanti

Nantilah pihak tolea meminta petunjuk kepada pihak yang dituakan.

\section{Gambar Prosesi Peminangan}

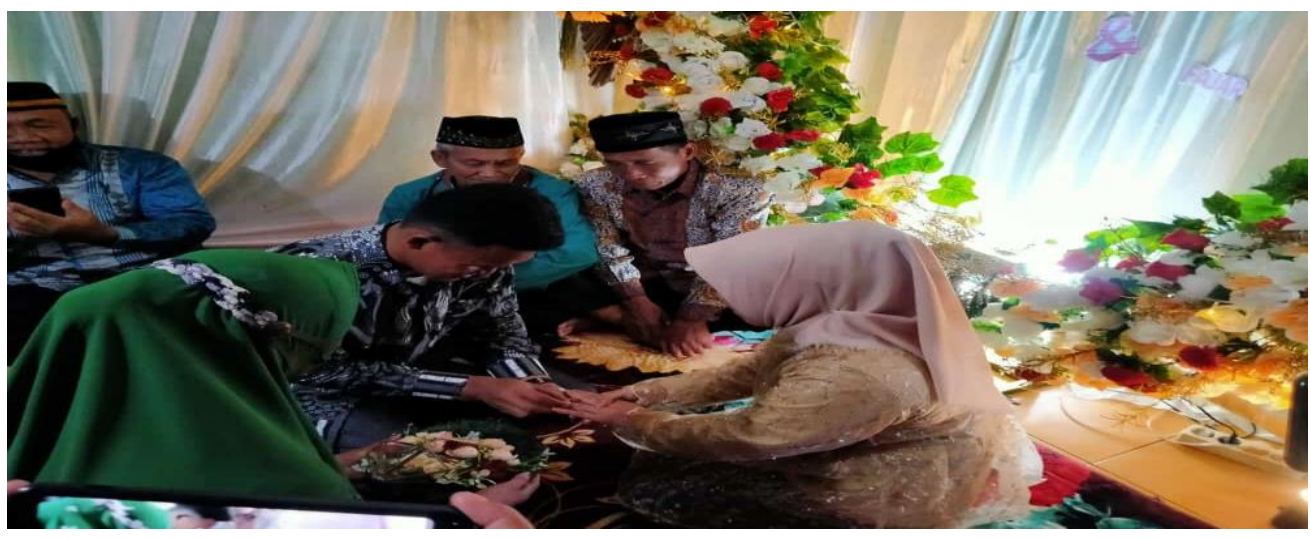

\section{Tahap Keempat Mowindahako (Penyelesaian Adat)}

Rangkaian terkahir dalam adat perkawinan orang tolaki adalah mowindahako yang acaranya sama dengan acara pada tahap ketiga tersebut diatas yakni:

1. Sara papalalo ine ulu sala / mbeparamesi (adat memohon izin untuk dimulainya acara kepada pemerintah) yang disertai dengan penyerahan uang dalam amplo sebesar Rp. 10.000 . disini tidak ada lagi penyerahan uang yang ditujukan untuk kas desa seperti ada acara mowawo niwule di atas.

2. Sara momberahi (adat memohon restu) kepada puutobu atau toono motuo disertai dengan menyerahkan uang dalam amplop dari tolea kepada puutobu atau toono motuo sebesar antara Rp. 25.000 sampai dengan Rp. 50.000.

3. Sara mombepedeehi (adat bertanya) kepada pabitara dengan menyerahkan uang dalam amplop sebesar Rp. 10.000 - Rp. 25.000.

4. Sara mowindahako.

Pada tahap keempat Sara mowindahako atau adat penyerahan seserahan adat), pihak keluarga laki-laki harus menyerahkan semua hal yang telah disepakati dalam musyawarah pinesambepeako pada tahap ke tiga tersebut diatas. Sambil menyerahkan seserahan adat dari pihak laki-laki yang diwakili oleh tolea kepada pihak perempuan yang diwakili oleh pabitara.

\section{Implementasi Bahasa Adat Mombesara}

Bahasa adat adalah salah satu bahasa yang digunakan masing-masing suku dalam melaksanakan upacara atau ritual-ritual adat berdasarkan kepercayaan suku atau tradisi masing-masing suku yang berada di Sulawesi Tenggara. Baik itu suku Tolaki, Muna, Buton, Wanci, Bugis, ataupun yang lainnya. Pada penelitian ini implementasi bahasa adat fokus pada implementasi bahasa adat bahasa suku tolaki yang berada di salah satu provinsi Sulawesi Tenggara, dimana bahasa adat ini sering sekali digunakan dalam ritual pada upacara adat Mombesara pada perkwinan suku tolaki. Dalam ritual tersebut bahasa adat tolaki yang dimaksud adalah bahasa asli suku tolaki atau bahasa daerah tolaki 
Bahasa daerah sebagai salah satu kekayaan bangsa memiliki fungsi sebagai alat komunikasi bagi masyarakat pendukungnya. Selain sebagai alat komunikasi intraetnik, bahasa daerah juga berfungsi sebagai pendukung bahasa nasional, yakni bahasa Indonesia. Atas dasar fungsi ini seharusnya bahasa daerah terus dibina dan dikembangkan dalam rangka memperkukuh ketahanan budaya bangsa. Bahasa daerah sebaiknya tidak lagi diperlakukan sebagai salah satu kebudayaan yang fungsinya dapat diganti oleh fungsi bahasa lain. Pasal 36 UUD 1945 menyebutkan, antara lain, bahwa bahasa daerah yang dipelihara dengan baik oleh para penuturnya akan dihormati dan dipelihara oleh negara karena bahasa-bahasa daerah tersebut merupakan sebagian dari kebudayaan Indonesia yang hidup. Kebijakan Bahasa Nasional merumuskan bahwa dalam hubungannya dengan perkembangan kehidupan kenegaraan di Indonesia ke arah pemerintahan otonomi daerah serta pentingnya pembinaan dan pelestarian budaya daerah, bahasa daerah perlu diberi kesempatan yang seluas-luasnya memainkan peranan yang lebih besar. Pemantapan keberadaan dan kesinambungan bahasa daerah bertujuan melindungi bahasa daerah yang merupakan salah satu kekayaan bangsa. Bahasa Indonesia sebagai bahasa yang dinamis dapat memanfaatkan kosakata bahasa daerah sebagai pemerkaya kosakata bahasa Indonesia. Sikap ini tidak hanya memantapkan kebudayaan daerah, tetapi juga memantapkan kebudayaan nasional.

Pada upacara adat perkawinan suku tolaki di kendari penerapan atau implementasinya sangat dilaksanakan dengan aturan-aturan yang berlaku. Seperti pada percakapan diatas yang dilaksanakan dibeberapa bagian tempat, sebut saja di kecamatan Puwatu tepatnya di kelurahan Lalodati. Proses bahasa adat yang mereka laksanakan mengacu pada peraturan Hukum-hukum adat suku tolaki. Dimana pelaksanaan tersebut pihak dari calon mempelai laki-laki bersuku Muna, tetapi pada pada pelaksanaan jajak pendapatnya menggunakan bahasa adat tolaki. Dikarenakan pihak dari calon mempelai perempuan bersuku Tolaki. Tentunya dalam hal ini dapat dikatakan bahwa penggunaan bahasa adat tolaki akan selalu terjaga apabila terus diperhatikan hukum-hukum adat yang berlaku.

Kemudian pada prosesi adat Mowawo niwule atau Peminangan Resmi yang dilaksanakan di Kecamatan Wua-wua tepatnya di Kelurahan Mataiwoi, juga masih tetap terjaga dengan baik penggunaan bahasa adat tolaki dalam prosesi adat peminagan. Pada proses tersebut pihak calon mempelai perempuan orang tua dari ibu bersuku bugis tetapi orang tua dari perempuan tersebut bersuku tolaki, tetapi pada proses tersebut tetap menggunakan bahasa adat suku tolaki dalam pelaksanaan ritual tersebut. Upacara tersebut menggunakan Bahasa adat tolaki dikarenakan orang tua dari calon mempelai perempuan bersuku tolaki.

Begitupun juga pada tahap yang lainnya yang dilaksanakan di kecamatan Mandonga kelurahan Wawombalata dan di kecamatan Wua-wua kelurahan Anawai tetap terjaga dengan baik menggunakan bahasa adat suku tolaki apabila pihak perempuan bersuku tolaki, walaupun pada keadaan saat ini berbeda suasananya hanya menghadirkan beberapa tokoh adat, agama dan masyarakat karena mengikuti himbauan pemerintah untuk tetap menjalankan protokol kesehatan, tidak mengumpulkan massa yang banyak dikarenakan untuk memutus mata rantai penyebaran Virus Covid 19, seperti kebiasaan normal apabila prosesi adat dilaksanakan tentunya banyak sanak keluarga dan tetangga yang turut hadir dalam acara tersebut, tetapi kali ini suasananya sangat beda dikarenakan hanya beberapa orang saja yang turut ikut andil dalam acara tersebut. 


\section{SIMPULAN}

Proses upacara adat mombesara suku tolaki dapat dismpulkan terbagi dari beberapa bagian, dimana bagian yang pertama adalah tahap Tahap Morake-rakepi (mengikuti dan meninjau calon istri). Tahap Monduutudu (tahap pelamaran jejaka). Tahap Mowawo niwule (tahap pelamaran sesungguhnya) dan Tahap mowindahako (tahap upacara perkawinan/pernikahan). Dari keempat Prosesi adat tersebut masih terjaga dengan baik dan dilakukan oleh beberapa pembicara tokoh adat di kendari. Pembicara tersebut dari pihak perempuan yaitu Pabitara kemudian dari pembicara pihak laki-laki yaitu Tolea.

\section{DAFTAR PUSTAKA}

Abdurrahman.1978. Kedudukan Hukum Adat dalam Rangka Pembangunan Nasional. Bandung: Alumni

Chaer, Abdul dkk.1995. Sosiolinguistik Suatu Pengantar. Jakarta: Rineka Cipta.

Dasanti.2010. Ensiklopedia Lembaga Kemasyarakatan. Semarang:CV Ghyyas Putra.

Djajasudarma, T, Fatimah.2010. Metode Linguistik. Bandung: Refika Aditama.

Endraswara, S.2006. Metodologi Penelitian Kebudayaan. Yogyakarta: Gajah Mada University Press.

Endraswara, S.2006. Metode Teori dan Teknik Penelitian Kebudayaan Ideologi dan Epistemologi Aplikasi. Yogyakarta: Gajah Mada University Press.

Faruk. 1994. Pengantar Sosiologi Sastra. Yogyakarta: Pustaka Belajar.

Hadikusuma, Hilman. 1992. Pengantar ilmu hukum adat Indonesia. Bandung: Mandar maju.

Ihromi, TO.1999. Bunga Rampai Sosiologi Keluarga. Jakarta:Yayasan Obor Indonesia.

Judweng, S.2008. Tradisi Lisan dan Modernisasi. Refleksi Penelitian Sosial Positif dan Penelitian Partisipatif"Dalam Pudentia MPSS"2008.Metodologi kajian Tradisi Lisan (ATL) Jakarta.

Kaplan, D. dan AA Manners.1999.Teori Budaya.Yogyakarta:Pustaka Belajar.

Kridalaksana, Harimurti.1984.Kamus Linguistik Edisi Kedua.Jakarta:Gramedia.

Koentjaraningrat.1985.Masyarakat Desa di Indonesia Masa Kini.Jakarta : UI

Liliweri, Alo.2003. Makna Budaya dalam Komunikasi Antar Budaya. Yogyakarta: LKIS 
Leech Geoffrey. 1993. Prinsip-prinsip Pragmatik. Jakarta : Universitas Indonesia (UIPress)

Tarimana, Abdurrauf.1993.Konsep Mohepulei Wonua, Budaya Kepemimpinan pada Masyarakat Tolaki Provinsi Sulawesi Tenggara. Suatu Tinjauan Antropologi dan Sosiologi Politik.Kendari:FISIP UNHALU.

Wigjodipurno, Surojo. 1979. Pengantar dan Azas-Azas hukum adat. Bandung:Alumni 